\title{
FAKTOR-FAKTOR KETERLAMBATAN STUDI MAHASISWA PENDIDIKAN GEOGRAFI FAKULTAS ILMU SOSIAL UNIVERSITAS NEGERI PADANG
}

\author{
Aprizal Buansah \\ Program Studi Pendidikan Geografi \\ Fakultas Ilmu Sosial Univeritas Negeri Padang \\ Email: aprizalbuansah@gmail.com
}

\begin{abstract}
ABSTRAK
Penelitian ini bertujuan untuk mendeskripsikan faktor-faktor keterlambatan penyelesaian studi mahasiswa Pendidikan Geografi tahun masuk 2010-2013 Jurusan Geografi Fakultas Ilmu Sosial Universitas Negeri Padang.

Jenis penelitian ini adalah deskriptif kualitatif. Penelitian ini dilakukan di Jurusan Geografi FIS UNP. Informan dalam Penelitian ini ditentukan dengan teknik Purposive Sampling yaitu teknik pengambilan sampel sumber data dengan pertimbangan tertentu. Dengan melakukan wawancara, observasi dan dokumentasi.

Penelitian ini menemukan: (1) faktor internal penyebab keterlambatan penyelesaian studi yaitu ketidakmampuan informan untuk mengambil kesempatan dan mengatur waktu dengan baik untuk menyelesakan studinya. Selain itu minat, bakat, dan motivasi, serta tingkat kecerdasan informan yang masih kurang yang menyebabkan hasil belajar kurang memuaskan, (2) Faktor eksternal keadaan lingkungan dan faktor-faktor instrumental berpengaruh terhadap proses belajar informan namun tidak mempengaruhi keterlambatan studi.
\end{abstract}

Kata Kunci:Keterlambatan Studi, Faktor Internal, Faktor Eksteranl

\section{ABSTRACT}

This study aims to describe the factors of delay in the completion of the study of Geography Education students in 2010-2013 Department of Geography Faculty of Social Sciences Universitas Negeri Padang.

The type of this research is descriptive qualitative. This research was conducted in Geography Department of FIS UNP. Informants in this study is determined by Purposive Sampling technique is the data source sampling technique with certain considerations. By conducting interviews, observation and documentation.

This study found: (1) internal factors causing delays in the completion of the study ie the inability of informants to take the opportunity and set the time well to finish his studies. In addition, interest, talent, and motivation, as well as the level of informant intelligence is still lacking that lead to less satisfactory learning outcomes. (2) External factors of environmental conditions and instrumental factors affect the informant's learning process but not affect the delay in the study.

Keywords: Study Delay, Internal Factors, External Factors

1 Artikel ini ditulis dari skripsi Aprizal Buansah dengan judul Faktor-faktor Keterlambatan Studi Mahasiswa Pendidikan Geografi Fakultas Ilmu Sosial Universitas Negeri Padang

2 Dosen Jurusan Geografi Fakultas Ilmu Sosial Universitas Negeri Padang Dosen Pembimbing I Drs.Surtani, M.PddanPembimbing II Dr. Khairani, M.Pd 


\section{PENDAHULUAN}

Menurut Undang-undang No. 23 Tahun 2003 tentang sistem pendidikan Nasional, "Pendidikan adalah usaha sadar dan terencana untuk mewujudkan suasana belajar dan proses pembelajaran agar peserta didik secara aktif mengembangkan potensi dirinya untuk memiliki kekuatan spiritual keagamaan, pengendalian diri, kepribadian, kecerdasan, akhlak mulia, serta keterampilan yang diperlukan dirinya, masyarakat, bangsa, dan negara".

Pendidikan merupakan suatu kebutuhan yang mendasar yang harus dipenuhi oleh setiap individu baik secara formal maupun informal. Secara formal, Universitas Negeri Padang (UNP) merupakan salah satu perguruan tinggi yang menyelenggarakan pendidikan di bidang kependidikan dan non kependidikan yang bertujuan untuk mengembangkan sumber daya manusia (SDM) yang berkualitas serta berlandaskan iman dan taqwa kepada Tuhan Yang Maha Esa. Hal ini sesuai dengan visi misi UNP yakni menjadi salah satu universitas unggul di kawasan Asia Tenggara di bidang ilmu kependidikan, ilmu pengetahuan, teknologi, olahraga, dan seni pada tahun 2020 berdasarkan ketakwaan kepada Tuhan Yang Maha Esa, dan misinya yakni menyelenggarakan tridharma perguruan tinggi di bidang kependidikan dan non kependidikan yang berkualitas dan demokratis melalui pengoptimalan sumber daya secara mandiri dan kerjasama antar lembaga, berdasarkan nilai-nilai ketaqwaan.

Menurut peraturan menteri riset, teknologi, dan pendidikan tinggi Republik Indonesia Nomor 44 Tahun 2015 tentang standar nasional pendidikan tinggi pasal 16 ayat $1 \mathrm{~d}$ bahwa masa dan beban belajar program pendidikan sarjana paling lama 7 tahun, dengan beban belajar mahasiswa paling sedikit 144 SKS. Aturan masa studi ini juga sesuai dengan peraturan akademik UNP pasal 20 ayat 2, yakni untuk program sarjana dengan beban sks 144 dan dapat ditempuh dalam waktu kurang dari 8 semester.

Beban studi mahasiswa untuk tiap semester ditentukan oleh indeks prestasi (IP). Berdasarkan peraturan Akademik UNP pasal 20 ayat 6, Jika IP mahasiswa diatas 2,00 maka dapat mengambil beban studi sebanyak 18 SKS untuk setiap semesternya, bila diakumulasikan untuk 8 semester mahasiswa tersebut sudah mengambil beban studi sebanyak 144 SKS. Namun untuk beban mahasiswa berprestasi tinggi (3,014,00) setelah dua semester tahun pertama dapat ditambah hingga 64 jam per minggu setara dengan 24 SKS per semesternya. sehingga mahasiswa tersebut bisa menyelesaikan studinya tepat waktu.Sedangkan yang bermutu kualitatif sesuai dengan peraturan 
akademik UNP pasal 69 ayat 2 adalah lulusan sarjana dengan prediket kelulusan dengan pujian yakni dengan Indeks Prestasi Kumulatif (IPK) lebih dari 3,50.

Berkaitan dengan masa studi mahasiswa, jika dilihat fenomena yang terjadi dilapangan dari 34.061 jumlah mahasiswa UNP tahun masuk 2010-2103 hanya 22.314 mahasiswa yang telah menyelesaikan studinya terhitung peride juli-desember 2017. jika dipersentasikan hanya $65,5 \%$ dari total keseluruhan mahasiswa UNP tahun masuk 2010-2013.

Fakultas Ilmu Sosial dengan 5 jurusan yang dibawahinya yakni jurusan sejarah, jurusan sosiologi, jurusan geografi, jurusan ilmu sosial dan politik, dan jurusan ilmu administrasi negara dengan total jumlah 2.448 orang mahasiswa tahun masuk 2010, 2011, 2012, dan 2013, hanya 1469 orang yang mampu menyelesaikan studinya terhitung periode juli-desembeer 2017, jika dipersentasikan hanya mencapai $60 \%$. Peralihan dari pendidikan menengah ke pendidikan tinggi sering menimbulkan kesulitan bagi sebagian mahasiswa baru. Belajar dan hidup dikampus terasa berbeda dengan di SMA. Perlakuan yang diterima mahasiswa di perguruan tinggi berbeda dengan yang di alami siswa di sekolah. Di Perguruan Tinggi, banyak kegiatan yang harus dilakukan, seperti mengikuti kuliah, mengerjakan praktikum, membuat laporan, dan menempuh
ujian.Kegiatan akademik dan kehidupan kampus sering terasa berat. Belajar di Perguruan Tinggi merupakan sebuah perjuangan. Perjuangan itu yang meminta pengorbanan. Misalnya, pola hidup yang harus disesuaikan,waktu bersama teman yang harus dikurangi secara drastis. Penyesuaian itu semua sering terasa tidak menyenangkan (Ginting, 1997:1).

Berdasarkan hasil wawancara dengan beberapa mahasiswa Program Studi Pendidikan Geografi masalah lain yang sering dihadapi mahasiswa dalam menyelesaikan adalah kurangnya minat mahasiswa terhadap Jurusan Geografi itu sendiri yang mengakibatkan mahasiswa sering tidak masuk saat perkuliahan, kemampuan akademik mahasiswa yang kurang baik dapat dilihat dari hasil belajar tiap semester yang didapatkan. Faktor lainnya yaitu keadaan ekonomi keluarga yang kurang mampu memenuhi kebutuhan saat perkuliahan yang sebagian mahasiswa harus bekerja sampingan selain kuliah sebagai tugas utama dalam studinya, selanjutnya yaitu Program Pengalaman Lapangan Kependidikan yang dilaksanakan di semester delapan dan diluar kota mengakibatkan mahasiswa sulit membagi waktu untuk dapat menyelesaikan studinya tepat waktu.

Bila hal ini dibiarkan maka akan terjadi penumpukan mahasiswa yang menyebabkan terganggunya sub sistem perguruan tinggi yang lain 
serta akan menjadi kendala bagi UNP untuk mencapai visi misi menjadi universitas yang unggul dan bermutu tinggi. Menurut Prayitno (2015:279-280) masalah belajar memiliki bentuk yang banyak ragamnya, yang pada umunya dapat digolongkan atas keterlambatan akademik, ketercepatan dalam belajar, sangat lambat dalam belajar, kurang motivasi dalam belajar, bersikap dan berkebiasaan buruk dalam belajar.

Bayaknya mahasiswa UNP yang tidak mampu menyelesaikan studinya tepat waktu merupakan masalah belajar yang tergolong kepada keterlambatan akademik, yakni posisi mahasiswa yang sebenarnya mampu menyelesaikan studi tepat waktu akan tetapi karena beberapa faktor sehingga terlambat dalam penyelesaian studi.

Menurut Muhibbin Syah (2012:68), Secara umum belajar dapat dipahami sebagai tahapan perubahan seluruh tingkah laku individu yang relatif menetap sebagai hasil pengalaman dan interaksi dengan lingkungan yang melibatkan proses kognitif. Belajar ialah suatu proses usaha yang dilakukan seseorang untuk memperoleh suatu perubahan tingkah laku yang baru secara keseluruhan, sebagai hasil pengalamannya sendiri dalam interaksi dengan lingkungannya (Slameto, 2010:2). Hasil belajar bukan suatu penguasaan hasil latihan melainkan pengubahan kelakuan
(Hamalik, 2012:27). Dalam beberapa pendapat di atas terdapat hal mendasar yang disepakati dan dapat diambil kesimpulan bahwa dalam proses belajar terdapat perubahan dalam tingkah laku. Begitu pula halnya ketika belajar di Perguruan Tinggi, tetap yang dituntut adalah perubahan tingkah laku ke arah yang lebih baik.

Memasuki dunia perguruan tinggi berarti melibatkan diri dalam situasi hidup dan situasi akademis yang secara fundamental berbeda dengan apa yang pernah dialami dalam lingkungan sekolah lanjutan atas. Sebagai konsekuensinya, setiap orang yang memasuki perguruan tinggi wajib melakukan adaptasi dengan dunia perkuliahan, terutama adaptasi pola berfikir, belajar, berekreasi, bertindak/ beramal dalam mengamali kehidupan kampus (Burhanuddin, 2004:1).

Peralihan dari pendidikan menengah ke pendidikan tinggi sering menimbulkan kesulitan bagi sebagian mahasiswa baru. Belajar dan hidup di kampus terasa berbeda dengan di SMA. Perlakuan yang diterima mahasiswa di perguruan tinggi berbeda dengan yang dialami siswa di sekolah. Di Perguruan Tinggi, banyak kegiatan yang harus dilakukan, seperti mengikuti kuliah, mengerjakan praktikum, membuat laporan, dan menempuh ujian. Kegiatan akademik dan kehidupan kampus sering terasa berat. Belajar di Perguruan Tinggi merupakan sebuah 
perjuangan. Perjuangan itu yang meminta pengorbanan. Misalnya, pola hidup yang harus disesuaikan, waktu bersama teman yang harus dikurangi secara drastis. Penyesuaian itu semua sering terasa tidak menyenangkan (Ginting, 1997:1).

Di perguruan tinggi harus bisa belajar secara mandiri, tetapi bukan berarti tidak bekerjasama dengan teman. Mahasiswa di perguruan tinggi harus bisa berdiri sendiri, dalam artian untuk tidak bergantug kepada orang lain karena mahasiswa dituntut untuk lebih aktif dan mandiri. Kondisi umum jasmani dan tonus (tegangan otot) yang menandai tingkat kebugaran organ-organ tubuh dan sendi-sendinya, dapat mempengaruhi semangat dan intensitas siswa dalam mengikuti pelajaran. Kondisi organ tubuh yang lemah, dapat menurunkan kualitas ranah cipta (kognitif) sehingga materi yang dipelajarinya pun kurang atau tidak berbekas (Syah, 2012:146147).

Menurut Slameto (1995:54) kesehatan seseorang berpengaruh terhadap belajarnya. Proses belajar seseorang akan terganggu jika kesehatan seseorang terganggu, selain itu juga ia akan cepat lelah, kurang bersemangat, mudah pusing, ngantuk jika badannya lemah, kurang darah ataupun ada gangguangangguan atau kelainan-kelainan fungsi alat inderanya serta tubuhnya. Agar seseorang dapat belajar dengan baik haruslah mengusahakan kesehatan badannya tetap terjamin dengan cara selalu mengindahkan ketentuan-ketentuan tentang bekerja, belajar, istirahat, tidur, makan, olahraga, rekreasi, dan ibadah.

Suryabrata

(1989:10)

menyatakan bahwa orang yang belajar dalam keadaan segar jasmaninya akan mendapatkan hasil yang lebih bagus dari pada orang yang belajar dalam keadaan kelelahan. Begitu juga dengan anakanak yang kekurangan gizi, ternyata kemampuan belajarnya di bawah anak-anak yang cukup gizinya, karena mereka lekas lelah, mudah mengantuk, dan tidak mudah menerima pelajaran. Disamping kondisi fisiologis secara umum, hal yang tidak kalah pentingnya adalah kondisi panca indera, terutama penglihatan dan pendengaran. Sebagian besar yang dipelajari oleh manusia, dipelajarinya dengan menggunakan penglihatan dan pendengaran (Suryabrata, 1989:10).

Tingkat kesehatan indera pendengar dan indera penglihat sangat mempengaruhi kemampuan siswa dalam menyerap informasi dan pengetahuan, khususnya yang disajikan dalam kelas (Syah, 2012:147). Daya pendengaran dan penglihatan yang rendah akan menyulitkan proses menyerap itemitem informasi yang bersifat echoic dan iconic (gema dan citra). Akibat negatif selanjutnya adalah terhambatnya proses informasi yang 
dilakukan sistem memori peserta didik tersebut.

Secara umum faktor-faktor yang mempengaruhi proses dan hasil belajar ada dua, yaitu faktor luar (eksternal) dan faktor dalam (internal). Faktor luar dapat dibagi menjadi dua, yaitu (1) lingkungan, yang terdiri dari lingkungan alami dan lingkungan sosial, instrumental, yang meliputi kurikulum, program, sarana dan prasarana, serta dosen. Sedangkan faktor dalam juga dapat dibagi dua, yaitu (1) fisiologis, yang meliputi kondisi fisiologis umum dan kondisi panca indera, (2) psikologis, yang terdiri dari minat, kecerdasan, bakat, dan motivasi.

Kondisi umum jasmani dan tonus (tegangan otot) yang menandai tingkat kebugaran organ-organ tubuh dan sendi-sendinya, dapat mempengaruhi semangat dan intensitas siswa dalam mengikuti pelajaran. Kondisi organ tubuh yang lemah, dapat menurunkan kualitas ranah cipta (kognitif) sehingga materi yang dipelajarinya pun kurang atau tidak berbekas (Syah, 2012:146147).

Suryabrata

(1989:10)

menyatakan bahwa orang yang belajar dalam keadaan segar jasmaninya akan mendapatkan hasil yang lebih bagus dari pada orang yang belajar dalam keadaan kelelahan. Begitu juga dengan anakanak yang kekurangan gizi, ternyata kemampuan belajarnya di bawah anak-anak yang cukup gizinya, karena mereka lekas lelah, mudah mengantuk, dan tidak mudah menerima pelajaran.Disamping kondisi fisiologis secara umum, hal yang tidak kalah pentingnya adalah kondisi panca indera, terutama penglihatan dan pendengaran. Sebagian besar yang dipelajari oleh manusia, dipelajarinya dengan menggunakan penglihatan dan pendengaran (Suryabrata, 1989:10).

Tingkat kesehatan indera pendengar dan indera penglihat sangat mempengaruhi kemampuan siswa dalam menyerap informasi dan pengetahuan, khususnya yang disajikan dalam kelas (Syah, 2012:147). Daya pendengaran dan penglihatan yang rendah akan menyulitkan proses menyerap itemitem informasi yang bersifat echoic dan iconic (gema dan citra). Akibat negatif selanjutnya adalah terhambatnya proses informasi yang dilakukan sistem memori peserta didik tersebut.Menurut Arikunto (1988:82) sarana pendidikan merupakan semua penunjang bagi proses belajar mengajar. Sedangkan prasarana dapat diartikan sebagai segala sesuatu yang dapat memudahkan dan melancarkan pelaksanaan suatu usaha.

Sarana pendidikan umumnya mencakup semua fasilitas yang secara langsung dipergunakan dan menunjang proses pendidikan, seperti : meja, kursi, alat-alat atau media pendidikan dan sebagainya. 
Sedangkan yang dimaksud dengan prasarana adalah yang secara tidak langsung menunjang jalannya proses pendidikan, seperti : gedung, jalan, halaman dan lain sebagainya. Jadi sarana dan prasarana adalah alat penunjang keberhasilan suatu proses upaya yang dilakukan di dalam pelayanan publik, karena apabila kedua hal ini tidak tersedia maka semua kegiatan yang dilakukan tidak akan dapat mencapai hasil yang diharapkan sesuai dengan rencana.

Agar mahasiswa mendapat pengalaman yang lengkap sebagai pendidik, mahasiswa PLK harus melaksanakan kegiatan pembelajaran (teaching) dan di luarpembelajaran (nonteaching). Kegiatan pembelajaran adalah kegiatan belajar dan pembelajaran. Mahasiswa PLK melakukan kegiatan sebagaimana pendidik profesional melaksanakan pembelajaran di kelas. Kegiatan mencakup kegiatan perencanaan dan pelaksanaan pembelajaran, dan penilaian.PLK bertujuan untuk memberi pengalaman nyata kepada mahasiswa agar dapat merasakan dan menjiwai tugas-tugas pendidik. Diharapkan setelah menyelesaikan PLK, mahasiswa memiliki kompetensi pendidik (kompetensi pedagogik, profesional, kepribadian, dan sosial).

\section{METODE PENELITIAN}

Penelitian ini tergolong ke dalam jenis penelitian deskriptif kualitatif.
Fokus utama penelitian ini adalah menganalisis keterlambatan penyelesaian studi mahasiswa Pendidikan Geografi angkatan 20102013 dengan menjadi instrumen atau alat penelitian adalah peneliti itu sendiri dan orang yang dianggap lebih tahu dengan apa yang diharapkan.

Penelitian dilaksanakan di Kota Padang dimana pengambilan data dikampus Fakultas Ilmu Sosial Universitas Negeri Padang. Waktu penelitian dimulai sejak bulan November 2017.

Dalam penelitian ini yang dijadikan subjek penelitian adalah dua orang dosen geografi serta mahasiswa pendidikan geografi angkatan 2010 berjumlah 2 orang, angkatan 2011 berjumlah 3 orang, angkatan 2012 berjumlah 5 orang, angkatan 2013 berjumlah 5 orang di Jurusan Geografi Fakultas Ilmu Sosial Universitas Negeri Padang.

Dalam penelitian kualitatif, yang menjadi alat pengumpulan data atau instrumen penelitian adalah peneliti sendiri. Dalam pengumpulan data peneliti harus terjun langsung kelapangan tanpa bisa diwakili.

Agar data yang dibutuhkan dapat dikumpulkan dengan baik maka teknik pengumpulan data yang digunakan dalam penelitian ini adalah observasi, wawancara, dan dokumentasi. Setelah melakukan observasi dan wawancara, dilakukan pencatatan dan alat perekam, yang beertujuan untuk memperkuat 
keabsahan dan mendukung data yang diperoleh yang dilampirkan sesuai dengan data dan persoalan penelitian.

Beberapa langkah yang dapat dilakukan untuk menganalisis data menurut Sugiyono (2014:337) adalah reduksi data, penyajian data, dan pengambilan keputusan.Data yang diperoleh dicari maknanya dan diambil kesimpulan yang pada awalnya bersifat sementara, dan akan berubah bila tidak ditemukan buktibukti yang kuat yang mendukung pada tahap pengumpulan data berikutnya. Tetapi apabila kesimpulan yang dikemukakan pada tahap awal didukung oleh data-data yang valid dan konsisten saat peneliti kembali kelapangan mengumpulkan data, maka kesimpulan yang dikemukakan merupakan kesimpulan yang kredibel.

Keabsahan data diketahui melalui jawaban informan pada kaset data dan informan kepada waktu, tempat, dan situasi yang berbeda. Pemeriksaan keabsahan data diperoleh dengan beberapa cara antara lain adalah perpanjangan keikutsertaan, ketekunan pengamatan, pemeriksaan teman sejawat, dan triangulasi. Teknik Triangulasi adalah suatu teknik untuk memeriksa keabsahan data dengan memanfaatkan sesuatu di luar data untuk pengecekan atau sabagai pembanding terhadap data yang telah diperoleh.

Teknik

triangulasi

menggunakan berbagai cara seperti observasi, wawancara berstruktur, dokumentasi untuk menguji keakuratan data, triangulasi dalam pengujian kredibilitas data dilakukan dengan cara mengecek data yang telah diperoleh melalui beberapa sumber untuk menguji kredibilitas data.

\section{HASIL PENELITIAN DAN PEMBAHASAN.}

Banyaknya mahasiswa UNP yang tidak mampu menyelesaikan studinya tepat waktu merupakan masalah belajar yang tergolong kepada keterlambatan akademik, yakni posisi mahasiswa yang sebenarnya mampu menyelesaikan studi tepat waktu akan tetapi karena beberapa faktor sehingga terlambat dalam penyelesaian studi. Pada penelitian ini, peneliti mengkhususkan untuk melakukan penelitian tentang faktor internal dan faktor eksternal penyebab keterlambatan studi mahasiswa pendidikan Geografi. Setelah dilakukan penelitian terhadap faktorfaktor keterlambatan studi mahasiswa pendidikan Geografi tahun masuk 2010-2013 dapat diketahui bahwa:

\section{FaktorFisiologis}

Dari hasil penelitian di lapangan ditemukan bahwa faktor fisiologis secara umum dapat mempengaruhi proses belajar mahasiswa. Kondisi organ tubuh yang lemah, dapat menurunkan kualitas ranah cipta (kognitif) 
sehingga materi yang dipelajarinya pun kurang atau tidak berbekas (Syah, 2012:146-147).

Dalam sebuah penelitian skripsi pengaruh faktor internal fisiologis terhadap hasil belajar ekonomi siswa di SMA Negeri 1 Sidamanik oleh Agustina (2016) ditemukan bahwa berpengaruh secara signifikan dengan nilai $\mathrm{t}$ hitung $3,083>\mathrm{t}$ tabel 1,666 dengan sig 0,003 $<0,05$. Hal ini menunjukkan bahwa faktor fisiologis berpengrauh terhadap proses belajar. Proses belajar seseorang akan terganggu jika kesehatan seseorang terganggu, selain itu juga ia akan cepat lelah, kurang bersemangat, mudah pusing, ngantuk jika badannya lemah, kurang darah ataupun ada gangguangangguan atau kelainan-kelainan fungsi alat inderanya serta tubuhnya.

Berdasarkan temuan peneliti di lapangan dapat disimpulkan bahwa kondisi tubuh informan yang tidak bisa terlalu letih membuat mereka tidak boleh bekerja keras dan harus memiliki waktu yang cukup untuk istirahat.Namun hal ini tidak mempengaruhi keterlambatan studi mahasiswa yang bersangkutan.Karena mereka masih bisa kekampus untuk kuliah dan melakukan bimbingan skripsi dengan dosen.Pada semester tujuh informan telah menyelesaikan seluruh mata kuliah kecuali beberapa mata kuliah yang harus diulang karena gagal.Sehingga ada sebagian dari teman-teman informan yang telah dapat menyelesaikan studinya dalam waktu tujuh semester.Sedangkan panca indera, informan tidak mngalami masalah yang berarti walaupun ada sedikit gangguan saat belajar. Masalah tersebut bisa diatasi segera dengan sedikit istirahat dan menggunakan alat bantu seperti kaca mata untuk yang memiliki masalah dengan penglihatan.

2. FaktorPsikologis

Minat, bakat, motivasi dan tingkat kecerdasan seorang mahasiswa sangat mempengaruhi proses belajarnya di kampus. Menurut Hamalik (2012:33), murid yang cerdas akan lebih berhasil dalam kegiatan belajar, karena ia lebih mudah menangkap dan memahami pelajaran dan lebih mudah mengingat-ingatnya. Menurut Muhibbin Syah (2012:152) minat berarti kecendrungan dan kegairahan yang tinggi atau keinginan yang besar terhadap sesuatu. Menurut Muhibbin Syah (2012:151) setiap orang pasti memiliki bakat dalam arti berpotensi untuk mencapai prestasi sampai ketingkat tertentu sesuai dengan kapasitas masing-masing.

Berdasarkan temuan peneliti di lapangan dapat disimpulkan bahwa keadaan psikologis informan masih kurang baik. Motivasi mahasiswa terhadap Jurusan Geografi masih kurang, pada awal masuk ujian seleksi perguruan tinggi, geografi bukan merupakan pilihan pertama melainkan pilihan ke-2 dan ke-3, karena bakat dan minat yang tidak 
sesuai terhadap jurusan yang didapatkan hal ini berdampak pada motivasi mahasiswa dalam menjalani perkuliahan dan mengakibatkan hasil kuliah pada tiap semester kurang memuaskan. Sering keluar kelas dan tidak mengikuti proses perkuliahan. Mahasiswa tidak komitmen dengan proses perkuliahan yang dilaluinya. Berdasarkan peraturan Akademik UNP pasal 20 ayat 6, Jika IP mahasiswa di atas 2,00 maka dapat mengambil beban studi sebanyak 18 SKS untuk setiap semesternya, bila diakumulasikan untuk 8 semester mahasiswa tersebut sudah mengambil beban studi sebanyak 144 SKS. Namun untuk beban mahasiswa berprestasi tinggi (3,014,00) setelah dua semester tahun pertama dapat ditambah hingga 64 jam per minggu setara dengan 24 SKS per semesternya. sehingga mahasiswa tersebut bisa menyelesaikan studinya tepat waktu. Namun dengan adanya mata kuliah yang gagal dan harus mengulang pada semester berikutnya membuat mahasiswa tersebut harus menambah masa studi.

\section{Lingkungan}

Berdasarkan hasil penelitian ditemukan bahwa faktor lingkungan mempengaruhi kondisi belajar mahasiswa. Hal ini diperkuat oleh hasil penelitian dalam sebuah jurnal tentang Pengaruh Lingkungan Belajar dan Motivasi Belajar terhadap Prestasi Belajar Mata Pelajaran Ekonomi Siswa Kelas XI di MAN Keboan Tahun Pelajaran 2012-2013 oleh Bipit Nindya Ningrum yang menunjukkan bahwa lingkungan belajar dan motivasi belajar berpengaruh secara signifikan terhadap prestasi belajar. Temuan empiris tersebut mengindikasikan bahwa untuk meningkatkan prestasi belajar di MAN Keboan harus memperhatikan faktor seperti lingkungan belajar dan motivasi belajar.Dari hasil perhitungan variabel kualitas pelayan diperoleh koefisen sebesar 0,050 variabel harga koefisien sebesar 0.008 yang berarti bahwa lingkungan belajar dan motivasi belajar berpengruh signifikan terhadap prestasi belajar.

Berdasarkan temuan peneliti di lapangan dapat disimpulkan bahwa adanya pengaruh kenyamanan belajar di kampus yang dirasakan oleh informan yaitu akibat gedung kuliah yang selalu berpindah-pindah dan sarana pendukung kenyamanan seperti kipas angin atau AC belum cukup menampung kapasitas mahasiswa yang berada di dalam lokal sebelum gedung baru UNP. Sehingga yang dirasakan mahasiswa ketika itu yaitu keadaan suhu ruangan yang meningkat dan kondisi belajar yang kurang kondusif.Sedangkan pengaruh dari lingkungan sosial diciptakan oleh mahasiswa itu sendiri seperti keributan dan lain-lain. Faktor lingkungan sosial keluarga tidak memiliki pengaruh yang berarti 
dalam hal ini.Kebutuhan mahasiswa terpenuhi dari keluarga.

4. Instrumental

Faktor-faktor instrumental dirancang adanya dan penggunannya sesuai dengan hasil belajar yang diharapkan.Faktor-faktor

instrumental meliputi kurikulum, program, sarana dan fasilitas, serta guru (tenaga pengajar).Dalam perjalanannya kurikulum senantiasa mengalami perkembangan dan penyesuaian sesuai dengan kemajuan zaman.Kurikulum merupakan salah satu indikator yang menentukan berhasil tidaknya suatu pendidikan, oleh karena itu kurikulum harus dikelola secara baik dan profesional (Sagala, 2012:231).Temuan peneliti di lapangan dapat disimpulkan bahwa kurikulum tidak menjadi faktor penyebab keterlambatan studi mahasiswa. Informan merasa dapat menjalani kurikulum pembelajaran dengan baik saat proses perkuliahan.

Terkait kegiatan PPLK yang dilakukan di semester tujuh dan semester delapan tidak menjadikan program tersebut sebagai faktor penyebab keterlambatan studi mahasiswa karena masih adanya kesempatan yang diberikan untuk menyelesaikan tugas akhir/skripsi.Mata kuliah mahasiswa rata-rata sudah selesai disemester tujuh kecuali ada beberapa mata kuliah yang diulang karena gagal.Sehingga jika dilihat ada beberapa mahasiswa yang telah menyelesaikan studinya pada semester tujuh.

Terkait dengan sarana dan prasarana, Menurut Daryanto (2011:51) jenis peralatan dan perlengkapan yang disediakan dan cara-cara pengadministrasiannya mempunyai pengaruh besar terhadap program mengajar belajar. Persediaan yang kurang dan tidak memadai akan menghambat proses belajar mengajar. Demikian pula administrasinya yang jelek akan mengurangi kegunaan alat-alat tersebut dan perlengkapan tersebut. Dari wawancara yang dilakukan peneliti di lapangan dapat disimpulkan bahwa informan merasa sarana dan prasarana di kampus semakin membaik dan membuat lingkungan belajar semakin nyaman.

\section{PENUTUP}

\section{Kesimpulan}

Berdasarkan penelitian yang dilakukan di Universitas Negeri Padang Fakultas Ilmu Sosial Jurusan Geografi mengenai faktor keterlambatan penyelesaian studi Mahasiswa Pendidikan Geografi Tahun Masuk 2010-2013 dilihat dari faktor internal mahasiswa dan faktor eksternal mahasiswa, maka diperoleh kesimpulan sebagai berikut:

Faktor internal keadaan fisiologis berpengaruh terhadap proses belajar mahasiswa, namun hal ini tidak mempengaruhi keterlambatan studi mahasiswa itu 
sendiri. Karena mereka masih bisa kekampus untuk kuliah dan melakukan bimbingan skripsi dengan dosen.Ketidakmampuan informan untuk mengambil kesempatan dan mengatur waktu dengan baik membuat informan merasa kesulitan untuk menyelesakan studinya.Pada semester tujuh informan sebenarnya telah menyelesaikan seluruh mata kuliah kecuali beberapa mata kuliah yang harus diulang karena gagal sehingga bisa menyelesaikan studi di semester tujuh.Selain itu minat, bakat, dan motivasi, serta tingkat kecerdasan informan yang masih kurang yang menyebabkan hasil belajar kurang memuaskan dan harus mengulang mata kuliah pada semester-semester berikutnya.

Faktor eksternal keadaan lingkungan dan faktor-faktor instrumental berpengaruh terhadap proses belajar informan. Namun tidak mempengaruhi keterlambatan studi mahasiswa itu sendiri.Keadaan lingkungan belajar dan faktor-faktor instrumental yang telah dirancang untuk hasil belajar yang diinginkan semakin baik.

\section{Saran}

Setelahmelakukanpenelitianini adabeberapa saran yang inginpenulisberikanyaitu:

Menjaga kesehatan dengan pola makan dan tidur yang teratur serta tidak bergadang dalam mengerjakan tugas-tugas kuliah agar kebugaran jasmani tetap terjaga dan tidak mudah diserang oleh penyakit.
Mahasiswa harus berusaha menumbuhkan minat terhadap jurusan yang didapat saat ujian masuk perguruan tinggi SNMPTN agar dapat mengikuti pelajaran secara baik dan memaksimalkan ilmu yang didapat saat perkuliahan.

Sistem pelaksanaan PPLK harus dievaluasi dan diatur lagi waktu pelaksanaannya agar semakin baik.

Mahasiswa harus bisa mengatur waktu untuk fokus dalam penyelesaian tugas akhir/skripsi.

Adanya jadwal bimbingan skripsi terhadap mahasiswa agar lebih efektif dan efesiensi waktu dalam penyelesaian tugas akhir/skripsi.

\section{DAFTAR PUSTAKA}

Ginting, Cipta. 1997. Kiat Belajar di Perguruan Tinggi. Bandung: ITB.

Hamalik, Oemar. 2012. Proses Belajar Mengajar. Jakarta: Bumi Aksara.

Prayitno dan Erman Amti. 2015. Dasar-dasar Bimbingan dan Konseling. Jakarta: Rineka Cipta.

Sagala, Syaiful. 2012. Konsep dan Makna Pembelajaran. Bandung: Alfabeta

Salam, Burhanuddin. 2004. Belajar yang Sukses di Perguruan Cara Tinggi. Jakarta: Rineka Cipta.

Slameto. 1995.Belajar dan Faktorfaktor yang Mempengaruhinya. Jakarta: Rineka Cipta. 
Sugiyono. 2014. Metode Penelitian

Pendidikan. Bandung:

Alfabeta.

Suryabrata, Sumadi. 1989. Proses

Belajar-Mengajar

$d i$

Perguruan Tinggi. Yogyakarta:

Andi Offset

Syah, Muhibbin. 2012. Psikologi Belajar. Jakarta: Rajawali Press.

Ningrum, Bipit N. 2013. Pengaruh Lingkungan Belajar dan Motivasi Belajar terhadap Prestasi Belajar Mata Pelajaran Ekonomi Siswa

Kelas XI di MAN Keboan Tahun Pelajaran 2012-2013. (skripsi). STKIP PGRI JOMBANG.

Sinaga, Agustina S. 2016. Pengaruh

Faktor Psikologis dan Fisiologis Siswa terhadap Prestasi Belajar Ekonomi SMA Kelas X SMA Negeri 1 Sidamanik. (Skripsi). FE. Unimed.

Undang-undang No. 23 tahun 2003 tentang Sistem Pendidikan Nasional. Peraturan Mentri Riset Teknologi dan Pendidikan Tinggi Republik Indonesia No. 44 tahun 2015 tentang Standar Nasional Pendidikan Tinggi. Peraturan Akademik UNP pasal 20. 